\title{
Contribution to the Hydrochemical Study of Groundwater from the Continental Terminal in Saloum
}

\author{
Sakhel Ndong1, Baba Ngom²*, Saidou Ndao', Alioune Ly², Saliou Ngom³ ${ }^{3}$, Séni Tamba² \\ ${ }^{1}$ UFR Sciences \& Technologies, University Iba Der Thiam of Thies, Thies, Senegal \\ ${ }^{2}$ Laboratory of Sciences and Technologies of Water and Environment (LaSTEE), Polytechnic School of Thies (EPT), Thies, Senegal \\ ${ }^{3}$ Société Nationale des Eaux du Senegal (SONES), Dakar, Senegal \\ Email: ^bngom@ept.sn
}

How to cite this paper: Ndong, S., Ngom, B., Ndao, S., Ly, A., Ngom, S. and Tamba, S. (2022) Contribution to the Hydrochemical Study of Groundwater from the Continental Terminal in Saloum. Journal of Water Resource and Protection, 14, 51-71.

https://doi.org/10.4236/jwarp.2022.142004

Received: December 27, 2021

Accepted: January 25, 2022

Published: January 28, 2022

Copyright (C) 2022 by author(s) and Scientific Research Publishing Inc. This work is licensed under the Creative Commons Attribution International License (CC BY 4.0).

http://creativecommons.org/licenses/by/4.0/

cc) (i) Open Access

\begin{abstract}
This paper focuses on the study of the aquifer of the Continental Terminal in the south of Saloum river. This study aims to participate in the knowledge of the physicochemical quality and to help understand the origins and processes of the mineralization of the water of the Continental Terminal (CT). Physicochemical treatments show an average $\mathrm{pH}$ of 6.61 indicating a slightly acidic water overall. The electrical conductivity varies between 37.4 and $12,320 \mu \mathrm{S} \cdot \mathrm{cm}^{-1}$ with an average of $729.3 \mu \mathrm{S} \cdot \mathrm{cm}^{-1}$. High conductivities are recorded around the ocean and the Saloum River, indicating higher mineralized waters in these areas. The geochemical study and multivariate statistical analysis indicate three groups of the sampled waters. Group 1 is mainly formed of the $\mathrm{Ca}-\mathrm{HCO}_{3}$, $\mathrm{Na}-\mathrm{HCO}_{3}, \mathrm{Ca}-\mathrm{Cl}$ and $\mathrm{Na}-\mathrm{Cl}$ facies. This group is the most common one and is found throughout the southern Saloum area. Group 2, mainly made up of the $\mathrm{Ca}-\mathrm{HCO}_{3}$ and $\mathrm{Na}-\mathrm{HCO}_{3}$ facies, is located in the center, east, west and north of the zone. The mineralization of these two groups is believed to be of carbonate, evaporitic and/or anthropogenic origin. Group 3 is formed from the $\mathrm{Na}-\mathrm{Cl}$ facies. This group is located in the north and west of the area (near the ocean and the Saloum river). This group 3 suggests pollution of marine and anthropogenic origin. The calculated base indices suggest cationic exchanges between the waters and the formations of the water table of the terminal continental.
\end{abstract}

\section{Keywords}

Continental Terminal Aquifer, Saloum, Physico-Chemical Quality, Mineralization, Geochemistry, Multivariate Statistical Analysis 


\section{Introduction}

Between the end of the 1960s and of the 1990s, West Africa was affected by transformations from a significant decrease in rainfall [1]. This decrease in rainfall is a result of climate change. In Senegal, new climate variations are perceived through precipitation and temperatures [2]. The decrease in rains and high temperatures in the southern area of Saloum lead to a decrease in surface runoff and freshwater inflows. The salinity of surface waters in this area is increasing. High salinities are observed (greater than $60 \mathrm{~g} / \mathrm{l}$ ) and may be (greater than $140 \mathrm{~g} / \mathrm{l}$ ) during the dry season, in the upstream part of the Saloum river estuary throughout the year [1]. Work carried out in the area [1] [3] [4], indicated significant values of salinity in the Saloum estuary, which may even exceed the salinity of seawater. As a result, surface waters are dominated by a high salt content except for temporary runoff in the rainy season. Groundwater is therefore the main source of water for the population. Thus, with the presence of brackish water in places, found in the Maastrichtian water table and high fluorine contents that may exceed WHO standards [1], the Continental Terminal (CT) water table is the major source of water for the inhabitants of the area. In this area of Saloum, the population's water supply is mainly based on the exploitation of groundwater from the Continental Terminal aquifer [5]. Due to the decrease in rainfall, high temperatures and population growth in the area, groundwater recharge decreases, evaporation and pumping increases. Consequently, the Continental Terminal (CT) water table in its coastal area is exposed to saline intrusion. According to Fadili [6], high pumping in coastal areas decreases the potential of the existing aquifer, by penetrating marine waters, changing its quality, following an imbalance between fresh water and water from the sea. Today, the local population has given up operating wells because of their high chloride content (3195 $\mathrm{mg} / \mathrm{l}$ ) [7]. In many arid and semi-arid regions, the intrusion of salt water into coastal and continental aquifers is a widespread phenomenon that can sometimes irreversibly degrade the fate of these waters [3]. Several studies have been carried out in this southern zone of Saloum [8] [9] [10] [11] [12]. These studies focus on geology, hydrogeology, major and minor ion hydrogeochemistry, isotopes and hydrogeological modeling. They made it possible to identify the sources of salinity, the mechanisms and degree of salinization, the surface water-groundwater relationships in this southern area of Saloum [13] [14] [15] [16] [17]. These authors indicated that in addition to the appearance of salt water on the coastal part, the increase in the salinity of the waters of the Saloum River also contributes to the contamination of groundwater in this southern area of Saloum [8]. These studies aim to understand the Saloum system to allow its good management. The detection and monitoring of salinity are essential in the mechanisms of its intrusion into coastal aquifers, within the framework of sustainable management of water resources [3]. Our objective is to participate in the knowledge of the physicochemical quality of the water of the Continental Terminal (CT) groundwater and to contribute to understanding the origins and 
processes of the mineralization of these water sources.

\section{Materials and Methods}

\subsection{Study Site}

The study area (Figure 1) is located in central western Senegal, between latitudes $13^{\circ} 35^{\prime}$ and $14^{\circ} 10^{\prime} \mathrm{N}$, and between longitudes $15^{\circ} 40^{\prime}$ and $16^{\circ} 30^{\prime} \mathrm{W}$. This southern area of Saloum is limited to the north by the Saloum River, south by the border of Gambia, west by the Atlantic Ocean and east by the Kaffrine region. The climate in the area is Sudano-Sahelian, with the alternation of a wet season and a dry season. Altitudes in the area vary from 0 (western and northern part) to around $40 \mathrm{~m}$ (central, southern and eastern). The hydrographic network in the area is mainly made up of the Saloum river with its two branches (Diomboss and Bandiala), the Néma, the bolons, the Djikoye and the Baobolon.

Geologically, the study context is that of the Senegalese-Mauritanian basin. This basin is from Meso-Cenozoic to Quaternary with at its base a Precambrian to Paleozoic bedrock which rises to the surface on its eastern and south-eastern side [18].

For Lienou, two-thirds of the Senegalese-Mauritanian basin is made up of

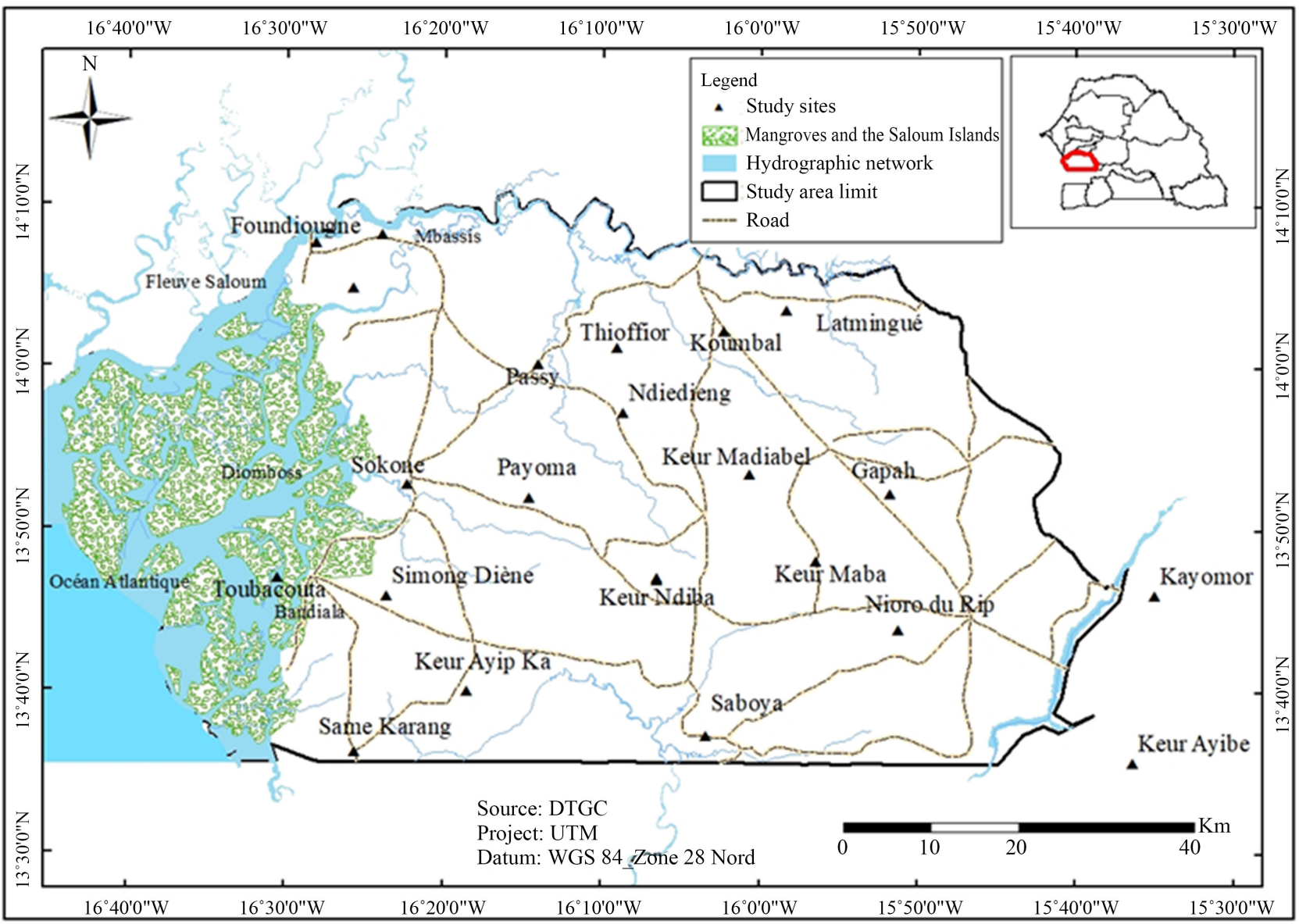

Figure 1. Study area and location of measured and sampled points. 
clayey, armored sands, generally variegated [19]. In the alternating phase of hot and humid climates, at the end and start of the Pliocene and Pleistocene respectively, a lateritic modification involves a deposit of armor that surpasses the Continental Terminal [3]. The Continental Terminal (CT) is made up of detrital terrain, characterized by significant ferralitic modifications accompanied by ferruginous deposits and armor-cladding, high variations of silica, neoformation of kaolinite [7]. Faye recognizes from stratigraphic correlations of borehole logs capturing the CT (Figure 2): a diversity of detrital formations, coarse sand, fine sand, clayey sand and sandy clay, irregular and alternated by variations of clay [3]. The Continental Terminal has a heterogeneous lithology, the deposits are detrital, clayey to gravels, and this is often encountered in continental dumping grounds, that is to say, continental sediments redistributed by marine sedimentation [8]. The sedimentation of the Continental Terminal is heterogeneous and consists mainly of fine and medium sand, clay, clayey sand, sandy clay, laterite, lateritic sand, silt, limestone, marl limestone and limestone-marly. The Continental aquifer Terminal occupies most of the territory of Senegal, in the southern zone (Sine-Saloum-Gambia), it is formed of intercalation of sands and clays, while in Ferlo it is sands, sandstones and clays [3]. This aquifer is contained in the sandy, sandy-clay and clay deposits of the Continental Terminal and the Quaternary. According to Diluca, its thickness increases from $20 \mathrm{~m}$ in Kaolack, to more than $100 \mathrm{~m}$ to the south [9]. To the west and north near the Saloum river, the thickness is $20 \mathrm{~m}$, it becomes higher towards the center with $80 \mathrm{~m}$ in Keur Madiabel (thalweg zone) and $100 \mathrm{~m}$ in north of Keur Samba Gueye (thalweg zone) [3]. Based on a review of several studies carried out in the Sine-Saloum-Gambia zone [3] [7] [8] [9] [10] [15], and archives of the Direction of Water Resources Management and Planning (DGPRE), hydraulic conductivities vary between $9.0 \times 10^{-7}$ and $1.0 \times 10^{-1} \mathrm{~m} / \mathrm{s}$ and transmissivity values (T) are between $1.8 \times 10^{-4}$ and $7.0 \mathrm{~m}^{2} / \mathrm{s}$. The storage coefficients (S) obtained from

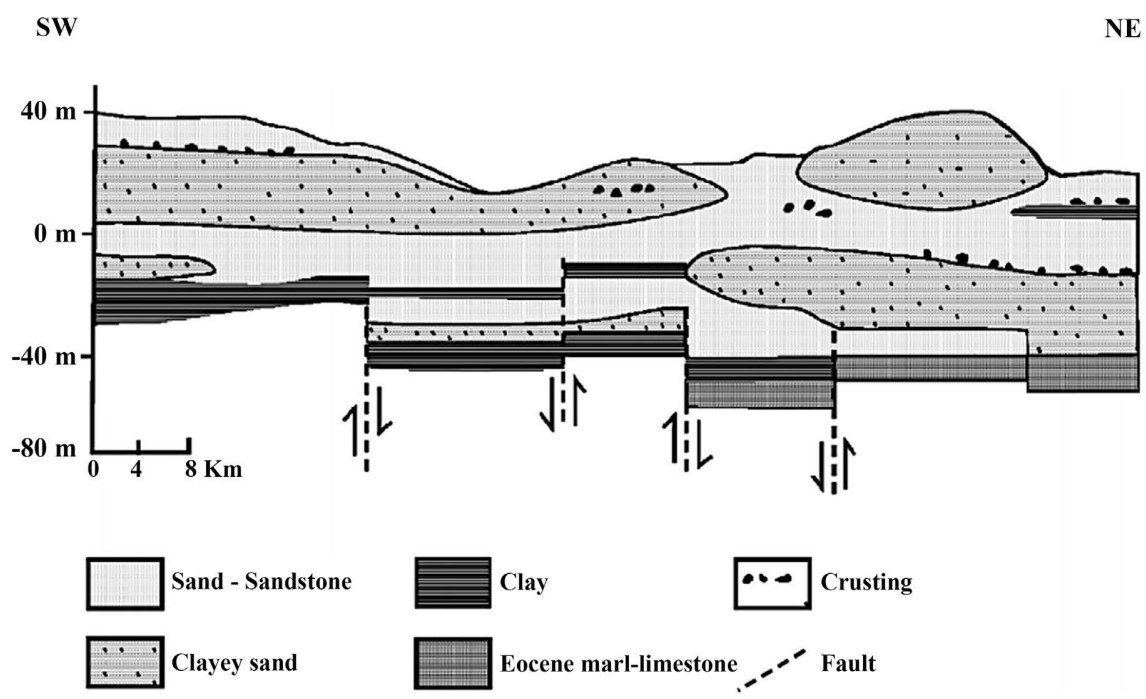

Figure 2. Study area geological cross section. Source: Faye et al. [12]. 
pumping test and the coefficients obtained from drilling reports, in view of the drinking water distribution network in the zone are between $8.0 \times 10^{-3}$ and $3.6 \times$ $10^{-2}[9]$.

\subsection{Sampling and Physicochemical Analysis}

Temperature, $\mathrm{pH}$ and electrical conductivity (EC) were measured in situ at 46 water points (wells and boreholes) in February 2019 using a multiparameter probe. Ten (10) samples are taken in plastic bottles from wells and boreholes in April 2019. At these water points, the temperature, electrical conductivity (EC) and $\mathrm{pH}$ are measured in situ. The bottles are then stored in coolers for transport to the laboratory. The chemical analyzes of the elements were carried out in the hydrochemical laboratory of the Geology Department of Cheikh Anta Diop University of Dakar (UCAD) and in the sanitation laboratory of Polytechnic School of Thies. These analyses focused on magnesium $\left(\mathrm{Mg}^{2+}\right)$, calcium $\left(\mathrm{Ca}^{2+}\right)$, sodium $\left(\mathrm{Na}^{+}\right)$, potassium $\left(\mathrm{K}^{+}\right)$ions, chlorides $\left(\mathrm{Cl}^{-}\right)$, nitrates $\left(\mathrm{NO}_{3}^{-}\right)$, bicarbonates $\left(\mathrm{HCO}_{3}^{-}\right)$, sulphates $\left(\mathrm{SO}_{4}^{2-}\right)$ and fluorides $\left(\mathrm{F}^{-}\right)$. These ions analyses were carried out by ion chromatography (Dionex-AQUION). Analysis results of 14 water points (boreholes, wells and piezometers) were obtained from a database of Direction of Water Resources Management and Planning (DGPRE) in January 2018. These results relate to cations $\left(\mathrm{Mg}^{2+}, \mathrm{Ca}^{2+}, \mathrm{Na}^{+}, \mathrm{K}^{+}\right)$and anions $\left(\mathrm{Cl}^{-}\right.$, $\mathrm{NO}_{3}^{-}, \mathrm{HCO}_{3}^{-}, \mathrm{SO}_{4}^{2-}, \mathrm{F}^{-}$).

The points were located with their geographic coordinates using GPS (Global Positioning System).

These coordinates were used to represent the spatial distribution of the water points sampled with ArcGIS software (Figure 1).

\subsection{Data Processing}

The methods applied to process the analysis results are based on Ion balance (BI) analysis, Piper diagram, Base Exchange indices (i.e.b.), Saturation Indices (SI), binary diagrams and multivariate statistical analysis.

\subsubsection{Ion Balance Analysis}

The study of ionic balance (BI) can help to verify the accuracy of test results. The results of analyses can be considered good if this ionic balance is less than $5 \%$, for a value of the balance between $5 \%$ and $10 \%$, the results can be maintained and when the balance is greater than $10 \%$, the analyzes are to be rejected [20].

The ionic balance is given by the following Equation (1):

$$
\mathrm{BI}(\%)=\frac{\sum \text { cations }-\sum \text { anions }}{\sum \text { cations }+\sum \text { anions }} \times 100
$$

where

BI (Ionic Balance);

$\sum$ cations: sum of major cations in water in milliequivalents;

Eanions: sum of major anions in water in milliequivalents. 


\subsubsection{Piper's Diagram}

The Piper diagram allows a classification of water. This classification is based on a representation of the chemical facies of water on a triangle of cations (left), anions (right) and an associated diamond giving a synthesis of the overall facies. The approximate location of an analytical result on each of these two triangles gives the first clarification on the anionic and cationic dominance [21]. This Piper hydrochemical diagram is mainly used in the literature to display the chemical facies of a set of water samples [22] [23].

The Piper diagram is used with the help of Diagramme software for the processing of hydrochemical data.

\subsubsection{Base Exchange Indice (i.e.b.)}

Changes in the chemical quality of water during its movement in the aquifer can be highlighted by the base exchange index (i.e.b.) [24] [25]. The i.e.b. expresses the relationship between the ions exchanged and the ions of the same nature originally existing in water. This index gives the nature of the ionic exchanges between water and the surrounding land using Equation (2) [22] [25]:

$$
\text { i.e.b. }=\frac{\left[\mathrm{Cl}^{-}\right]-\left(\left[\mathrm{Na}^{+}\right]+\left[\mathrm{K}^{+}\right]\right)}{\left[\mathrm{Cl}^{-}\right]}
$$

where:

$\left[\mathrm{Cl}^{-}\right]$: concentration in meq/l of chloride ions;

$\left(\left[\mathrm{Na}^{+}\right]+\left[\mathrm{K}^{+}\right]\right)$: concentration in meq/l of the sum of sodium and potassium ions. So:

- if i.e.b. is negative, the $\mathrm{Ca}^{2+}$ and $\mathrm{Mg}^{2+}$ ions of the water are replaced by the $\mathrm{K}^{+}$ and $\mathrm{Na}^{+}$ions of the surrounding formations;

- if i.e.b. is positive, the $\mathrm{Na}^{+}$and $\mathrm{K}^{+}$ions of the water are substituted by the $\mathrm{Mg}^{2+}$ and $\mathrm{Ca}^{2+}$ ions of the surrounding lands;

- if i.e.b. $=0$, we have equilibrium between the chemical constitution of the water and the constitution of the surrounding land.

\subsubsection{Saturation Index (IS)}

The influence of chemical elements in geochemical mineralization processes can be given by the state of saturation, determined by the saturation index. This saturation index provides information on the level of chemical equilibrium of water with the mineral in the aquifer matrix, in water-rock relationships, as a measure of the mechanism of dissolution and/or precipitation [26]. The saturation index is defined by the logarithm of the ionic activity ratio (PAI) to the equilibrium constant $(K)$ (Equation (3)) [27]:

$$
\mathrm{IS}=\log \left(\frac{\mathrm{PAI}}{K}\right)
$$

where:

PAI: ionic product of the solution;

$K$ : equilibrium constant. 
Three cases are possible:

IS $<0$, the solution is undersaturated with respect to the mineral considered;

IS $=0$, indicates saturation;

IS $>0$, the solution is supersaturated.

Diagrams and PHREEQC Interactive software are used to calculate saturation indices with respect to minerals (calcite, aragonite, dolomite, anhydrite, gypsum and halite).

\subsubsection{Binary Diagrams}

The binary diagrams show on a $2 \mathrm{D}$ figure the variation of the concentrations of the different ions or the representation of ion concentrations as a function of the chlorides considered as conservative halogens and not impacted by redox phenomena and minerals with reduced solubility [28] [29]. These binary diagrams can be used to analyze mineralization from correlations between the concentrations of major elements. These linear correlations between some of the chemical variables also aid in the study of the origin of mineralization according to the type of relationship [1]. For Faye, binary diagrams make it possible to distinguish the geochemical mechanisms responsible for the chemical evolutions noted, in addition to specifying the types of water [10]. The chloride ion indicates the origin of the salt in the water, it is a mixing tracer absent in exchanges between water and rock and is not lost [29] [30] [31].

\subsubsection{Multivariate Statistical Analysis}

Multivariate statistical analysis applied in the processing of hydrochemical data is based on the techniques of Ascending Hierarchical Classification (AHC) and Principal Component Analysis (PCA). These analysis techniques reduce and classify the information resulting from hydrochemical data with the aim of explaining the process of water governance [22] [32] [33] [34]. They show similarities or dissimilarities by grouping chemical elements (variables) or individuals (water point) according to their chemical compositions.

\subsubsection{Ascending Hierarchical Classification}

The Ascending Hierarchical Classification (AHC) is an analysis assessing the similarity or difference between samples to give an indication of class association [35]. This analysis allows multiple data to be grouped and ordered into distinct classes on a graph to facilitate their interpretations. On this graph, the individuals are distributed in succession of nesting forming a classification tree, called a dendrogram. According to Ahmed, it is a method of hierarchical classification of parameters, widely used in earth sciences and in the processing of hydrochemical results [22]. The Ascending Hierarchical Classification (AHC) method is powerful for processing hydrochemical data and for establishing geochemical models [32] [33].

\subsubsection{Principal Component Analysis}

Principal Component Analysis (PCA) is a descriptive statistical technique that 
displays on a graph much more information forming a database [24] [36]. It thus makes it possible, from a graphical representation, to distribute the chemical elements on the basis of their contents in the sampled water by reducing the number of variables. PCA is a method which decreases variables by representing the point cloud in a two-dimensional subspace generated by factor axes [32] [37] [38] [39]; this analysis determines the essential elements making it possible to interpret the phenomena involved from correlation with the variables [40]. According to Ahmed, PCA is used to study the mechanisms governing the physico-chemical constitution of water and/or their origins, and it is a new descriptive method recommended by Farnham, Johannesson et al. [22] [41].

The Ascending Hierarchical Classification (CHA) and Principal Component Analysis (PCA) methods are processed using the XLSTAT software.

\section{Results and Discussions}

\subsection{Physicochemical Characteristics of Ground Water}

The temperature values vary between $23.20^{\circ} \mathrm{C}$ and $32.00^{\circ} \mathrm{C}$ with an average of $27.96^{\circ} \mathrm{C}$. The $\mathrm{pH}$ varies between 5.35 and 8.00 , with an average value of $6.61 \mathrm{in}$ dicating acidic water overall. The electrical conductivity (EC) varies between 37.4 and $12,320 \mu \mathrm{S} \cdot \mathrm{cm}^{-1}$ with an average of $729.3 \mu \mathrm{S} \cdot \mathrm{cm}^{-1}$. Indeed the smallest values of EC are observed from the center to the South and South-East of the zone, while the higher electrical conductivities are noted in the West (near the Ocean) and North (near the Saloum river). Electrical conductivities increase as one approaches areas contaminated by salt water from the ocean and the Saloum River [3]. Based on WHO standards (2008), Dieng Ndao differentiates between 2 categories of water in the CT aquifer: fresh water $(\mathrm{EC}<900 \mu \mathrm{s} / \mathrm{cm})$ and those which are salty (EC $>900 \mu \mathrm{s} / \mathrm{cm}$ ) [1].

The results of the analysis were subjected to an electric charge balance (ionic balance) between anions and cations to check their validity (Table 1). Samples which have an ionic balance greater than $10 \%$ in absolute value are discarded.

The concentrations of chlorides $\left(\mathrm{Cl}^{-}\right)$in water vary between 3.15 and 1152.60 $\mathrm{mg} / \mathrm{l}$ with an average of $118.07 \mathrm{mg} / \mathrm{l}$. High levels are measured near the Saloum river and the sea. These high values confirm possible contamination of the water table by the Saloum river and the sea [7]. The concentrations of potassium $\left(\mathrm{K}^{+}\right)$ and Sodium $\left(\mathrm{Na}^{+}\right)$vary respectively between 0.33 and $18.79 \mathrm{mg} / \mathrm{l}$ with an average of $3.18 \mathrm{mg} / \mathrm{l}$, and between 2.35 and $479.56 \mathrm{mg} / \mathrm{l}$ for an average of $51.78 \mathrm{mg} / \mathrm{l}$. With regard to the calcium $\left(\mathrm{Ca}^{2+}\right)$ and magnesium $\left(\mathrm{Mg}^{2+}\right)$ contents, they vary respectively between 2.00 and $219.66 \mathrm{mg} / \mathrm{l}$ for an average of $36.66 \mathrm{mg} / \mathrm{l}$, and between 1.20 and $93.36 \mathrm{mg} / \mathrm{l}$ with an average $10.81 \mathrm{mg} / \mathrm{l}$. For bicarbonates $\left(\mathrm{HCO}_{3}^{-}\right.$), they are between 15.25 and $372.10 \mathrm{mg} / \mathrm{l}$ with an average value of 85.65 $\mathrm{mg} / \mathrm{l}$, while sulphates $\left(\mathrm{SO}_{4}^{2-}\right.$ ) vary between 0.51 and $55,48 \mathrm{mg} / \mathrm{l}$ with an average of $6.15 \mathrm{mg} / \mathrm{l}$. Nitrates $\left(\mathrm{NO}_{3}^{-}\right)$vary between 0.24 and $200.44 \mathrm{mg} / \mathrm{l}$ for an average value of $22.95 \mathrm{mg} / \mathrm{l}$. Fluorides $\left(\mathrm{F}^{-}\right)$vary between 0.02 and $1.8 \mathrm{mg} / \mathrm{l}$. Some of these 
Table 1. Ionic balances of the samples.

\begin{tabular}{|c|c|c|c|c|c|c|c|c|c|c|c|c|}
\hline \multicolumn{13}{|c|}{ parameter (meq/1) } \\
\hline Site & Type $^{\mathrm{a}}$ & $\mathrm{HCO}_{3}^{-}$ & $\mathrm{Cl}^{-}$ & $\mathrm{SO}_{4}^{2-}$ & $\mathrm{NO}_{3}^{-}$ & $\mathrm{Ca}^{2+}$ & $\mathrm{Mg}^{2+}$ & $\mathrm{Na}^{+}$ & $\mathrm{K}^{+}$ & Sanion & Scation & $\mathrm{BI}(\%)$ \\
\hline Bamba Dalla Konteyen & Piézo.1 & 4.00 & 0.54 & 0.19 & 0.08 & 1.15 & 0.86 & 2.01 & 0.39 & 4.81 & 4.41 & -4 \\
\hline Kayemor & $\mathrm{F} 1$ & 0.25 & 0.33 & 0.28 & 0.08 & 0.43 & 0.11 & 0.30 & 0.02 & 0.94 & 0.87 & -4 \\
\hline Keur Andallah Villane $\mathrm{Pz}$ & Piézo.2 & 0.50 & 0.20 & 0.02 & 0.02 & 0.51 & 0.11 & 0.12 & 0.03 & 0.73 & 0.76 & 2 \\
\hline Keur Babou Kani Pt & Puits1 & 0.90 & 0.33 & 0.04 & 0.01 & 0.64 & 0.10 & 0.60 & 0.01 & 1.28 & 1.36 & 3 \\
\hline Keur Madiabel Pz1 & Piézo.3 & 0.50 & 4.76 & 0.06 & 0.09 & 1.78 & 0.59 & 3.30 & 0.03 & 5.41 & 5.70 & 3 \\
\hline Mandera Touba & Piézo.4 & 1.30 & 0.75 & 0.05 & 0.01 & 0.74 & 0.56 & 0.82 & 0.06 & 2.11 & 2.18 & 2 \\
\hline Medina Sabakh F2 & $\mathrm{F} 2$ & 0.40 & 0.09 & 0.02 & 0.02 & 0.24 & 0.13 & 0.10 & 0.01 & 0.53 & 0.48 & -5 \\
\hline Ndiagne $\mathrm{Pz}$ & Piézo.5 & 0.40 & 0.90 & 0.02 & 0.03 & 0.54 & 0.22 & 0.44 & 0.03 & 1.36 & 1.23 & -5 \\
\hline Ndiop Thiarène Pt & Puits2 & 0.30 & 1.67 & 0.03 & 0.01 & 1.00 & 0.20 & 1.10 & 0.06 & 2.01 & 2.36 & 8 \\
\hline Paoskoto & F3 & 3.60 & 1.00 & 0.14 & 0.28 & 3.68 & 0.93 & 0.25 & 0.02 & 5.03 & 4.88 & -2 \\
\hline Passy Ngayene Pz & Piézo.6 & 0.80 & 0.47 & 0.02 & 0.01 & 0.62 & 0.41 & 0.10 & 0.04 & 1.30 & 1.17 & -5 \\
\hline Passy & $\mathrm{F} 4$ & 6.10 & 32.02 & 1.16 & 0.18 & 9.42 & 7.78 & 20.85 & 0.27 & 39.45 & 38.31 & -1 \\
\hline Sokone (Ngayene) F2 & F5 & 0.45 & 1.00 & 0.03 & 0.13 & 0.46 & 0.10 & 1.00 & 0.05 & 1.61 & 1.62 & 0.2 \\
\hline Thianda Thiamene & Piézo.7 & 5.00 & 1.40 & 0.02 & 0.04 & 3.75 & 1.87 & 0.91 & 0.48 & 6.46 & 7.02 & 4 \\
\hline Ndiaffate & Puits3 & 2.15 & 0.76 & 0.11 & 0.01 & 1.80 & 0.40 & 0.60 & 0.05 & 3.03 & 2.85 & -3 \\
\hline Ndoffane foret (P2) & Puits4 & 0.80 & 27.06 & 0.29 & 3.23 & 10.98 & 4.42 & 13.92 & 0.48 & 31.39 & 29.80 & -3 \\
\hline Ndoffane foret (P3) & Puits5 & 0.60 & 1.19 & 0.01 & 0.01 & 0.56 & 0.28 & 0.86 & 0.04 & 1.81 & 1.75 & -2 \\
\hline Saboya & Puits6 & 0.80 & 1.28 & 0.06 & 1.66 & 0.80 & 0.16 & 2.59 & 0.06 & 3.81 & 3.61 & -3 \\
\hline Prokhane & Puits7 & 1.20 & 0.24 & 0.12 & 0.46 & 0.96 & 0.14 & 0.70 & 0.05 & 2.03 & 1.84 & -5 \\
\hline Nioro & Puits8 & 1.00 & 1.79 & 0.21 & 2.41 & 2.20 & 1.50 & 1.43 & 0.12 & 5.40 & 5.25 & -1 \\
\hline Paoskoto & Puits9 & 1.50 & 0.76 & 0.08 & 0.44 & 1.30 & 0.18 & 1.10 & 0.06 & 2.78 & 2.64 & -3 \\
\hline Keur Madiabel & F6 & 0.40 & 0.21 & 0.03 & 0.04 & 0.20 & 0.28 & 0.10 & 0.02 & 0.68 & 0.60 & -6 \\
\hline Saboya & F7 & 0.35 & 0.20 & 0.03 & 0.06 & 0.14 & 0.10 & 0.33 & 0.02 & 0.64 & 0.59 & -4 \\
\hline Ndiayène Moussa Ndiaye & F8 & 0.40 & 0.24 & 0.04 & 0.07 & 0.10 & 0.10 & 0.48 & 0.02 & 0.74 & 0.70 & -3 \\
\hline
\end{tabular}

${ }^{a}$ The samples were taken from different types of water sources: Piezometer (Piézo), Borehole (F) and Well (Puits).

levels exceed the OMS standards of $50 \mathrm{mg} / \mathrm{l}$ (for nitrates) and $1.5 \mathrm{mg} / \mathrm{l}$ (for fluorides).

\subsection{Hydrochemical Classification of Groundwater}

An analysis by ascending hierarchical classification is carried out from the results of the analysis. This analysis showing the dendrograms (Figure 3(a) and Figure 3(b)) allowed us to classify the water points into three groups.

The representation of the concentrations of major elements on the Piper diagram (Figure 4) gives the main chemical facies of water.

Group 1 is represented by most of the structures sampled (Well6, Well8, Well2, Piezo.2, Piezo.6, Well7, Piezo.4, Well9, F1, Piezo.3, Piezo.5, F5, Well1, F8, 


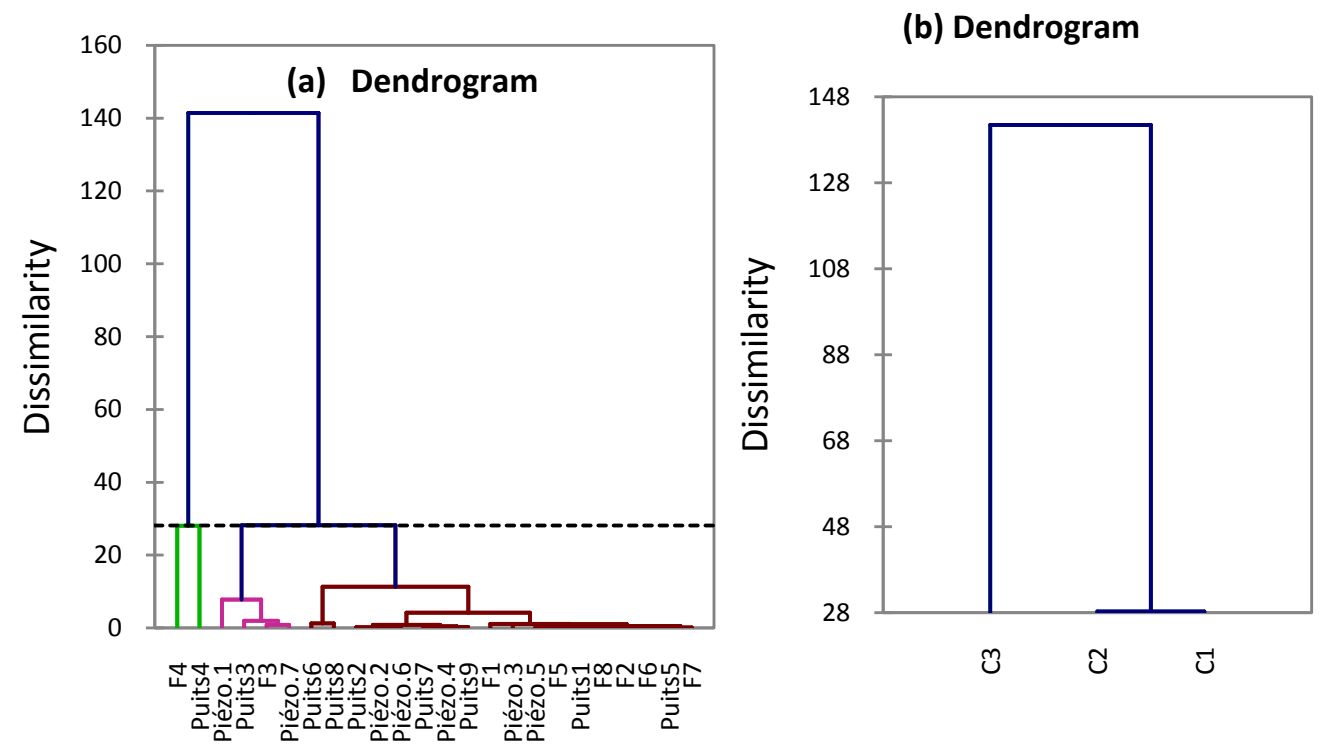

Figure 3. Ascending hierarchical classification dendograms.

F2, F6, Well5 and F7). This group is characterized by low mineralization with electrical conductivities varying between 48 and $653 \mu \mathrm{S} / \mathrm{cm}$, for an average of $204.1 \mu \mathrm{S} / \mathrm{cm}$. Group 1 does not have a particular geographical distribution. It is found in the center, North, South, East and West of the southern zone of Saloum. The distribution of the contents of the major elements is variable, $\mathrm{HCO}_{3}^{-}$ (between 15.25 and $91.5 \mathrm{mg} / \mathrm{l}$ ), $\mathrm{Cl}^{-}$(between 3.15 and $171.30 \mathrm{mg} / \mathrm{l}$ ), $\mathrm{Ca}^{2+}$ (between 2.00 and 43, $93 \mathrm{mg} / \mathrm{l}$ ), $\mathrm{Na}^{+}$(between 2.35 and $75.93 \mathrm{mg} / \mathrm{l}$ ), $\mathrm{Mg}^{2+}$ (between 1.20 and $18.27 \mathrm{mg} / \mathrm{l}$ ), $\mathrm{K}^{+}$(between 0.33 and $4.55 \mathrm{mg} / \mathrm{l}$ ), $\mathrm{SO}_{4}^{2-}$ (between 0.51 and $13.59 \mathrm{mg} / \mathrm{l}$ ) and $\mathrm{NO}_{3}^{-}$(between 0.24 and $149.51 \mathrm{mg} / \mathrm{l}$ ).

The main chemical facies in water are:

- the calcium bicarbonate facies $\left(\mathrm{Ca}-\mathrm{HCO}_{3}\right)$ (Piezo.2, Piezo.6, Well7, Well9, F1, F2 and F6);

- sodium bicarbonate facies $\left(\mathrm{Na}-\mathrm{HCO}_{3}\right.$ ) (Well6, Piezo. 4, Wells1, F8 and F7);

- he calcium chloride $(\mathrm{Ca}-\mathrm{Cl})$ and sodium $(\mathrm{Na}-\mathrm{Cl})$ facies (Well8, Piezo.5, Well2, Piezo.3, F5 and Well5).

Calcium bicarbonate and sodium bicarbonate facies dominate compared to the other facies. According to Dieng Ndao (2017), the low electrical conductivities characterizing freshwater of the $\mathrm{Ca}-\mathrm{Cl}$ facies type show significant areas of groundwater recharge at the terminal continental [1]. Despite its diversity, this group consists mainly of sites in the area with fresh water. Generally, the water of the groundwater is soft, but near the sea and the river, it is salty [10]. However, the high levels of nitrates in some works suggest contamination due to anthropogenic origin. Nitrates show that groundwater is contaminated by recently infiltrated water [8]. The calcium chloride facies $(\mathrm{Na}-\mathrm{Cl})$ present in the center of the zone which is characterized by fresh water is thought to be due to brackish water. Pockets of brackish water are increasing in the aquifer, although they are currently not well demarcated [15]. 


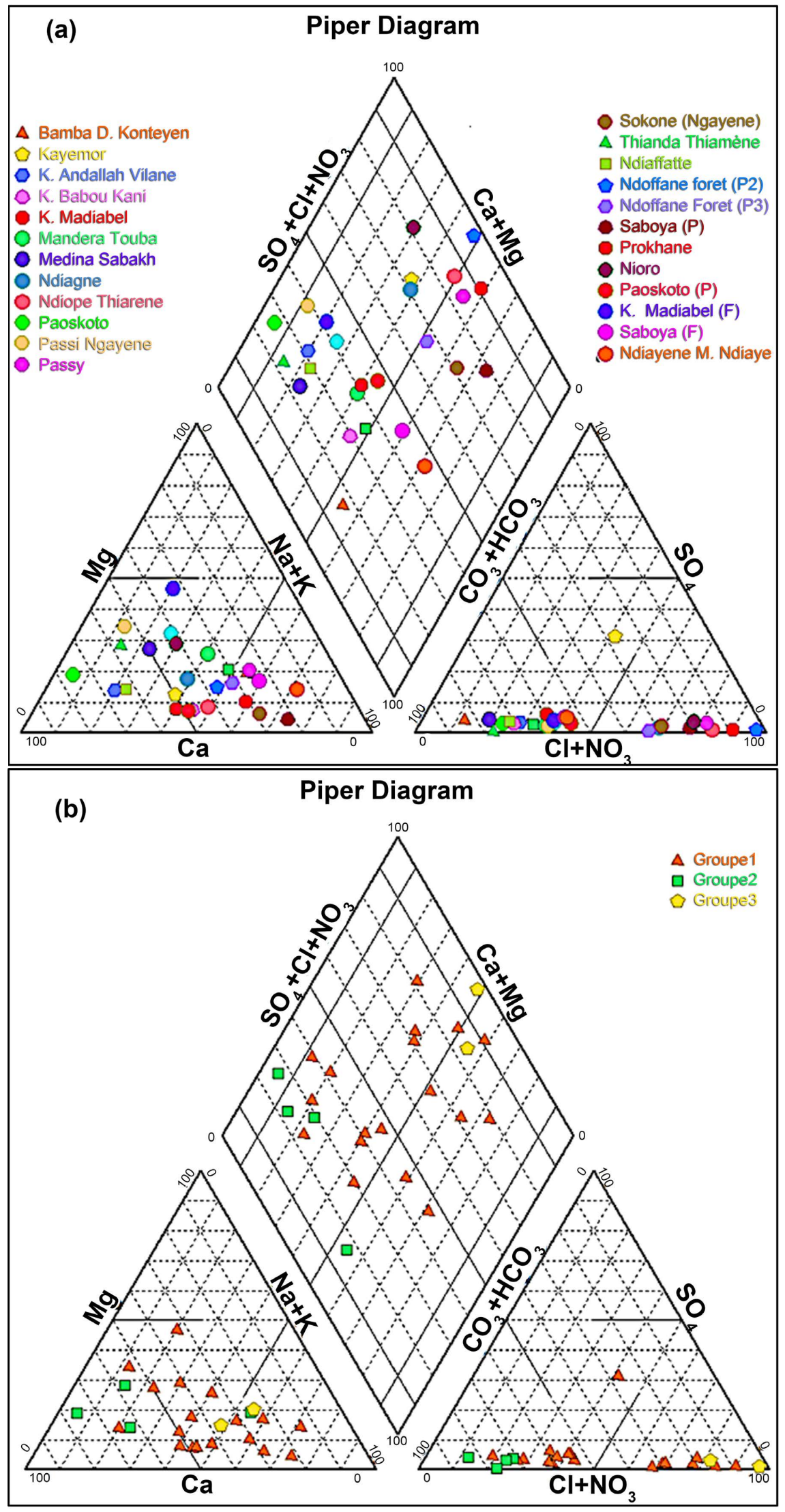

Figure 4. Piper diagram of: (a) Water facies; (b) With groups of structures. 
Group 2 is represented by the works (Piezo.1, Well3, F3 and Piezo.7). The electrical conductivity of this group varies between 296 and $656 \mu \mathrm{S} / \mathrm{cm}$ with an average of $469.5 \mu \mathrm{S} / \mathrm{cm}$. Changes in the content of major ions give, $\mathrm{HCO}_{3}^{-}$ (131.15 - $305.00 \mathrm{mg} / \mathrm{l}), \mathrm{Ca}^{2+}(23.00-75.00 \mathrm{mg} / \mathrm{l}), \mathrm{Cl}^{-}(19.31-50.40 \mathrm{mg} / \mathrm{l}), \mathrm{Na}^{+}$ (5.74 - $46.29 \mathrm{mg} / \mathrm{l}), \mathrm{Mg}^{2+}(4.89-22.48 \mathrm{mg} / \mathrm{l}), \mathrm{K}^{+}(0.6-15.10 \mathrm{mg} / \mathrm{l}), \mathrm{SO}_{4}^{2-} \quad(1.02-$ $9.12 \mathrm{mg} / \mathrm{l})$ and $\mathrm{NO}_{3}^{-}(0.32-8.82 \mathrm{mg} / \mathrm{l})$. The facies of this group are mainly of the calcium bicarbonate (east, center and north of the area) and sodium bicarbonate (center-west) types.

Group 3 is characterized by an electrical conductivity varying between 2900 and $4100 \mu \mathrm{S} / \mathrm{cm}$ for an average of $3500 \mu \mathrm{S} / \mathrm{cm}$. This group is represented by well 4 and F4 (Ndoffane forest and Passy). The waters of these localities correspond to the salty waters of the southern zone of Saloum. The concentrations of chloride $\left(\mathrm{Cl}^{-}\right)$and sodium $\left(\mathrm{Na}^{+}\right)$ions in these sites vary respectively between 960.80 and $1152.60 \mathrm{mg} / \mathrm{l}$, and between 320.09 and $479.56 \mathrm{mg} / \mathrm{l}$. The contents of anions and cations vary as follows: $\mathrm{Cl}^{-}>\mathrm{HCO}_{3}^{-}>\mathrm{NO}_{3}^{-}>\mathrm{SO}_{4}^{2-}>\mathrm{F}^{-}$and $\mathrm{Na}^{+}>$ $\mathrm{Ca}^{2+}>\mathrm{Mg}^{2+}>\mathrm{K}^{+}$. The facies of this group is a sodium chloride $(\mathrm{Na}-\mathrm{Cl})$ facies. These types of water show contamination by water from the sea and/or the Saloum River [1] [3] [7] [11] [15]. The high concentration of nitrate $\left(\mathrm{NO}_{3}^{-}\right)$in Ndoffane forest $(200.44 \mathrm{mg} / \mathrm{l})$ far exceeds the WHO standard $(50 \mathrm{mg} / \mathrm{l})$. This group 3 would highlight the contribution of human activities in the mineralization of the water of the terminal continental groundwater. The intensity of domestic and pastoral activities near wells without slabs and protective enclosures would promote percolation of rainwater to the water table [15].

\subsection{Water Mineralization}

\subsubsection{Base Exchanges Indices}

The base exchange indices (i.e.b.) of the sampled waters vary between -3.47 and 0.73 (Figure 5). Most of these water points have positive values with $58.3 \%$ of the indices. These positive clues indicate that $\mathrm{Mg}^{2+}$ and $\mathrm{Ca}^{2+}$ ions replace $\mathrm{Na}^{+}$

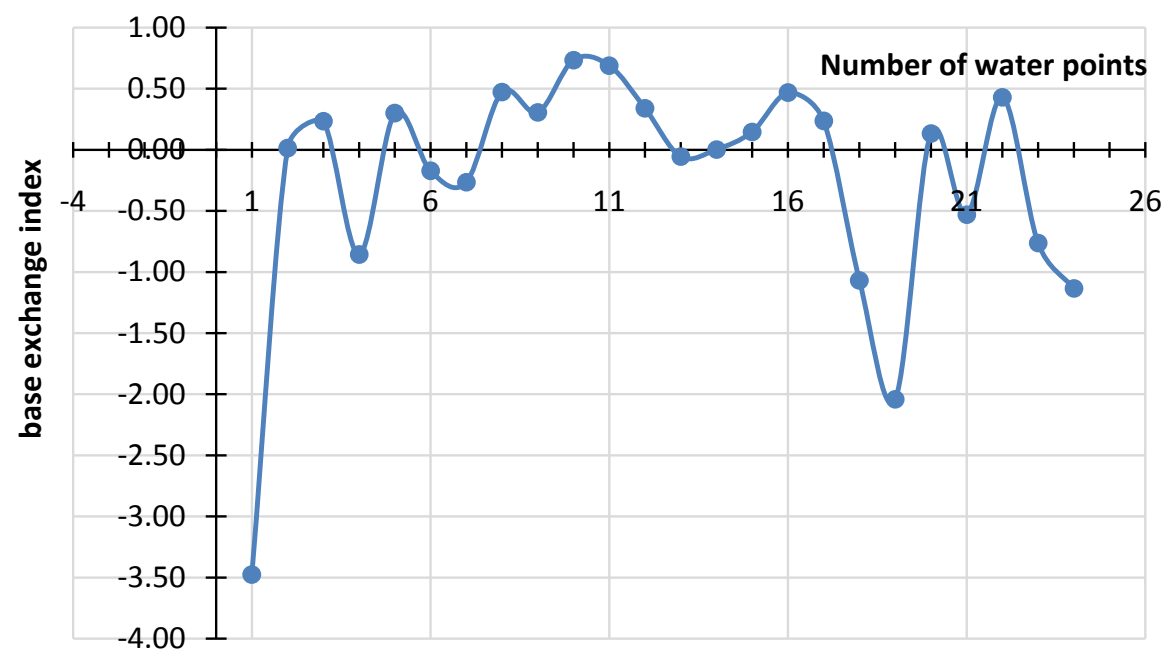

Figure 5. Change in base exchange index. 
and $\mathrm{K}^{+}$ions in water. In contrast, negative core trade indices represent $41.7 \%$. These negative indices indicate that the surrounding terrain releases $\mathrm{Mg}^{2+}$ and $\mathrm{Ca}^{2+}$ to fix the $\mathrm{Na}^{+}$and $\mathrm{K}^{+}$ions. The dominance of kaolinite-type clay is remarkable, over this cation exchange mechanism through clay minerals [11].

\subsubsection{Water Saturation Indices}

Box whisker (Figure 6) are represented from the calculation of the saturation indices. These boxes show that the waters are undersaturated with respect to all the minerals (calcite, aragonite, dolomite, anhydrite, gypsum, halite). Carbonate minerals (calcite, aragonite, dolomite) tend to approach saturation, while evaporitic minerals (anhydrite, gypsum, halite) are far from the saturation line.

The dissolution of these minerals would therefore participate in the mineralization of the water.

\subsection{Correlation Analysis of Physico-Chemical Parameters}

\subsubsection{Binary Diagrams}

Figure 7 shows the cross diagrams of the concentrations of major elements $\left(\mathrm{Na}^{+}\right.$, $\mathrm{Ca}^{2+}$, and $\left.\mathrm{Mg}^{2+}\right)$ with chlorides, $\left(\mathrm{Ca}^{2+}, \mathrm{HCO}_{3}^{-}\right)$with $\mathrm{Mg}^{2+}$ and $\left(\mathrm{HCO}_{3}^{-}, \mathrm{SO}_{4}^{2-}\right)$ with $\mathrm{Ca}^{2+}$. The distribution of points around the freshwater-saltwater mixing line can be adopted to determine other phenomena related to the mixing mechanism [31].

The representation of these major elements $\left(\mathrm{Na}^{+}, \mathrm{Ca}^{2+}\right.$ and $\left.\mathrm{Mg}^{2+}\right)$ with $\left(\mathrm{Cl}^{-}\right)$ indicates strong values of correlations. The correlation coefficients $(r)$ are greater than 0.9 (Figures $7(\mathrm{a})$-(c)). These correlation values would indicate a common source of these ions. This source could be marine and/or a dissolution of carbonate, evaporitic minerals. The high correlation between $\mathrm{Na}^{+}$and $\mathrm{Cl}^{-}$would be due to the same origin of a dissolution of halite and/or the presence of salt water [8]. The halite saturation index, undersaturated with respect to the water samples (Figure 6) could corroborate this. The representation of $\mathrm{Na}^{+}$as a function

Box plots + Moyenne

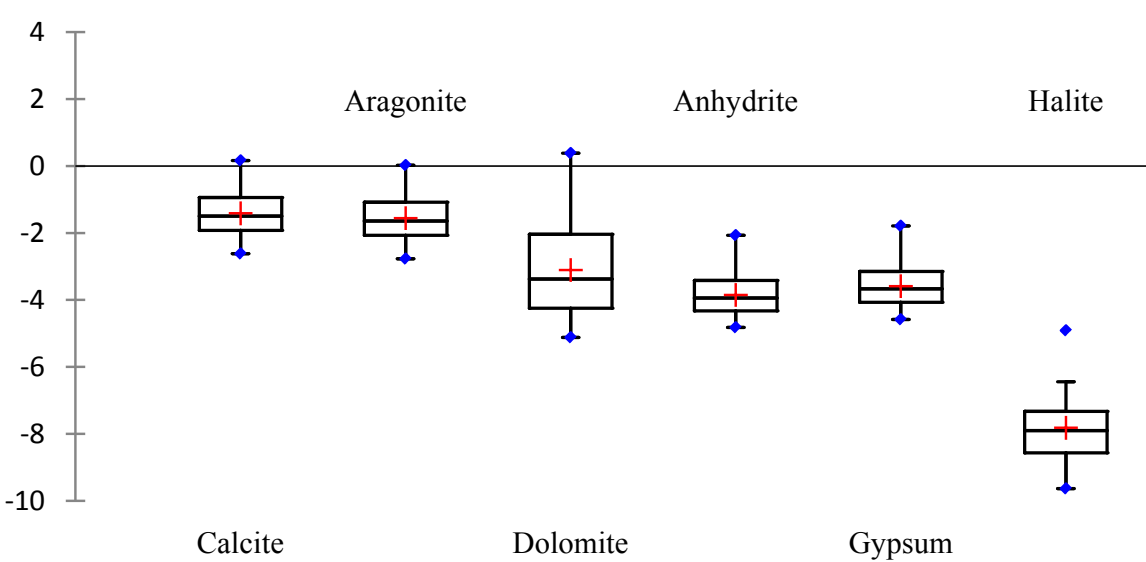

Figure 6. Water saturation indices with respect to, calcite, aragonite, dolomite, gypsum, halite and anhydride. 


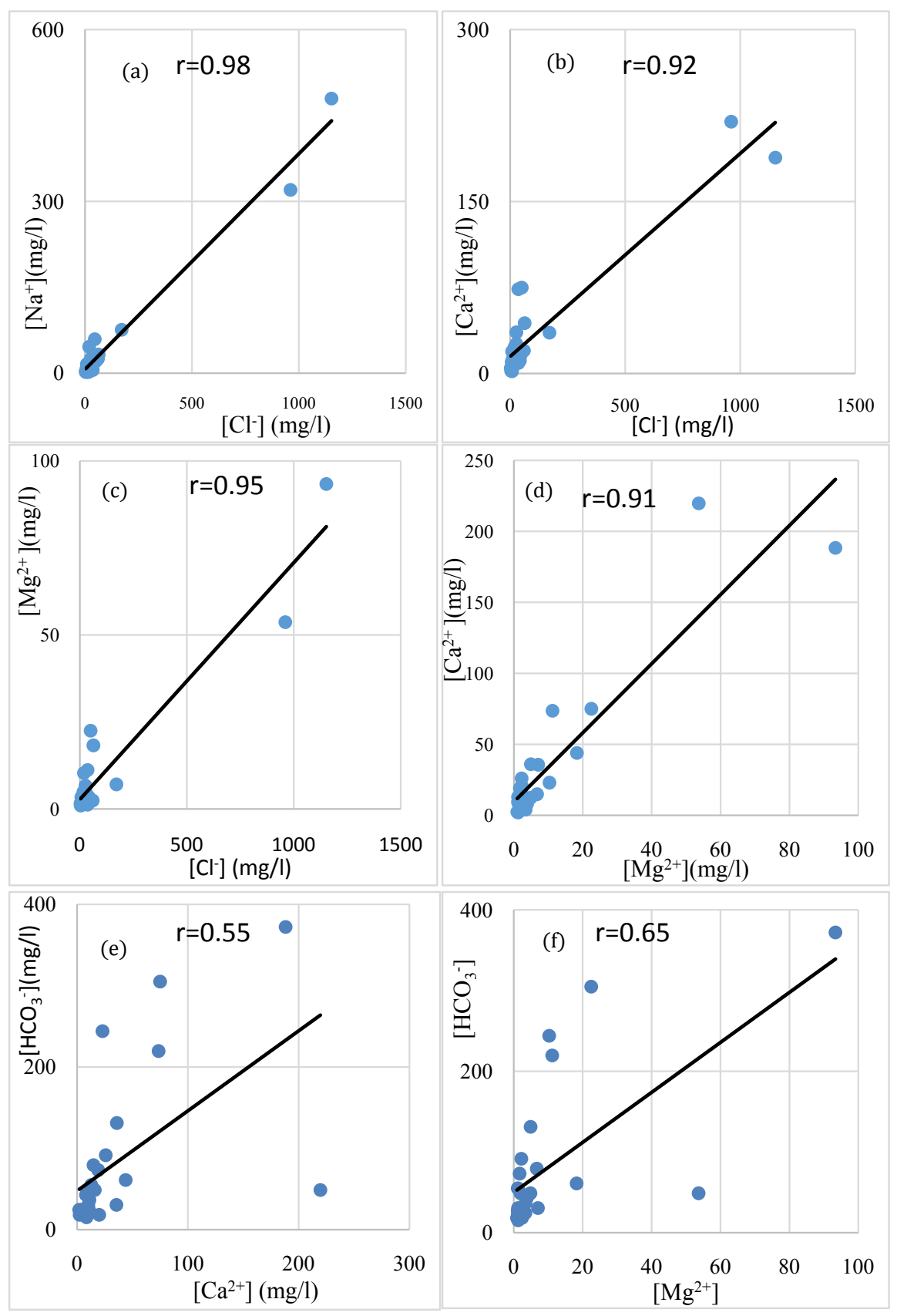

Figure 7. Binary diagrams showing relationships between the contents: (a) $\mathrm{Na}^{+} / \mathrm{Cl}^{-}$, (b) $\mathrm{Ca}^{2+} / \mathrm{Cl}^{-}$, (c) $\mathrm{Mg}^{2+} / \mathrm{Cl}^{-}$, (d) $\mathrm{Ca}^{2+} / \mathrm{Mg}^{2+}$, (e) $\mathrm{HCO}_{3}^{-} / \mathrm{Ca}^{2+}$, (f) $\mathrm{HCO}_{3}^{-} / \mathrm{Mg}^{2+}$.

of $\mathrm{Cl}^{-}$(Figure $\left.7(\mathrm{a})\right)(\mathrm{r}=0.98)$ indicates an important part of the points located on the mixing line and some placed above. The alignment of the points is made on the mixing line between two poles formed for a mixture of two waters, i.e. when the water is contaminated by salt water, on the sea water dilution line [42]. This representation shows a weak growth in sodium ion $\left(\mathrm{Na}^{+}\right)$. Enrichment/ depletion of $\mathrm{Na}^{+}$in fresh water would result from exchange of bases ensuring the progression of facies from $\mathrm{Ca}-\mathrm{Cl}$ or $\mathrm{Na}-\mathrm{Cl}$ or $\mathrm{Ca}-\mathrm{HCO}_{3}$ to $\mathrm{Na}-\mathrm{Cl}$ or $\mathrm{Na}-\mathrm{HCO}_{3}$ [10] [11]. The relationship between $\mathrm{Ca}^{2+}$ and $\mathrm{Mg}^{2+}$ (Figure 7(d)) shows a good 
correlation with $r=0.91$. On this relation, the arrangement of the points with respect to the mixing line favors an enrichment in magnesium $\left(\mathrm{Mg}^{2+}\right)$ compared to calcium $\left(\mathrm{Ca}^{2+}\right)$. The movements of the freshwater and seawater compositions are ensured by ion exchange reactions largely resulting from the enrichments and depletion of magnesium and calcium, respectively [22]. Thus, the representation of $\mathrm{Ca}^{2+}$ with $\mathrm{Cl}^{-}$(Figure $\left.7(\mathrm{~b})\right)(\mathrm{r}=0.92)$ would show this depletion of $\mathrm{Ca}^{2+}$ by a large part of the points placed at the bottom of the mixing line. The diagrams $\mathrm{HCO}_{3}^{-}$with $\mathrm{Ca}^{2+}$ and $\mathrm{HCO}_{3}^{-}$with $\mathrm{Mg}^{2+}$ (Figure $7(\mathrm{e}$ ) and Figure 7(f)) indicate correlation coefficients respectively $r=0.55$ and $r=0.65$.

For these representations, calcium and magnesium are better correlated with chlorides (Figure 7(b) and Figure 7(c)) ( $\mathrm{r}=0.92$ and $\mathrm{r}=0.95)$ than with bicarbonates. These results seem to confirm a common, marine origin of $\mathrm{Ca}^{2+}$ and $\mathrm{Mg}^{2+}$, especially in the northern and western parts of the area. However, calcium and magnesium would come from a dissolution of dolomite and/or calcite, since the waters are undersaturated with respect to these minerals (Figure 6). The degradation of minerals would lead, from a dissolution of calcite and/or feldspar to the presence of $\mathrm{Ca}^{2+}$ [14]. The enrichment in calcium relative to bicarbonate (Figure $7(\mathrm{e})$ ) would be due to a dissolution of calcite in the presence of $\mathrm{CO}_{2}$. In the group of fresh waters that are not contaminated by salty waters, the waters are often of calcium bicarbonate facies $\left(\mathrm{Ca}-\mathrm{HCO}_{3}\right)$ [8]. This type of $\mathrm{Ca}-\mathrm{HCO}_{3}$ facies occurs largely in the center, south and east of the southern Saloum area and is a characterization of freshwater. The relationship between $\mathrm{Ca}^{2+}$ and $\mathrm{SO}_{4}^{2-} \quad($ Figure $7(\mathrm{~g}))(\mathrm{r}=0.71)$ and the saturation index (Figure 6) of undersaturated water compared to gypsum indicate that calcium and sulfate ions would be bound to the dissolution of gypsum formations.

\subsubsection{Principal Component Analysis (PCA)}

Principal Component Analysis (PCA) is applied to major elements $\left(\mathrm{HCO}_{3}^{-}, \mathrm{Cl}^{-}\right.$, $\left.\mathrm{SO}_{4}^{2-}, \mathrm{NO}_{3}^{-}, \mathrm{Ca}^{2+}, \mathrm{Mg}^{2+}, \mathrm{Na}^{+}, \mathrm{K}^{+}\right)$, conductivity (EC) and $\mathrm{pH}$. This analysis gives the results of Table 2, Table 3 and Figure 8. The correlation matrix (Table 2)

Table 2. Correlation matrix (Pearson (n)) of elements, EC and $\mathrm{pH}$.

\begin{tabular}{ccccccccccc}
\hline Variables & $\mathbf{H C O}_{3}^{-}$ & $\mathrm{Cl}^{-}$ & $\mathbf{S O}_{4}^{2-}$ & $\mathbf{N O}_{3}^{-}$ & $\mathrm{Ca}^{2+}$ & $\mathbf{M g}^{2+}$ & $\mathbf{N a}^{+}$ & $\mathrm{K}^{+}$ & $\mathbf{E C}$ & $\mathbf{p H}$ \\
\hline $\mathbf{H C O}_{3}^{-}$ & 1 & & & & & & & & & \\
$\mathrm{Cl}^{-}$ & 0.445 & 1 & & & & & & & & \\
$\mathbf{S O}_{4}^{2-}$ & 0.634 & 0.828 & 1 & & & & & & & \\
$\mathbf{N O}_{3}^{-}$ & -0.091 & 0.436 & 0.156 & 1 & & & & & & \\
$\mathrm{Ca}^{2+}$ & 0.554 & 0.930 & 0.717 & 0.542 & 1 & & & & & \\
$\mathbf{M g}^{2+}$ & 0.656 & 0.951 & 0.897 & 0.351 & 0.914 & 1 & & & & \\
$\mathbf{N a}^{+}$ & 0.504 & 0.988 & 0.878 & 0.392 & 0.895 & 0.959 & 1 & & & \\
$\mathbf{K}^{+}$ & 0.398 & 0.714 & 0.526 & 0.566 & 0.739 & 0.669 & 0.707 & 1 & & \\
$\mathbf{E C}$ & 0.576 & 0.984 & 0.877 & 0.427 & 0.942 & 0.984 & 0.988 & 0.716 & 1 & \\
$\mathbf{p H}$ & 0.856 & 0.263 & 0.466 & -0.079 & 0.375 & 0.442 & 0.329 & 0.423 & 0.388 & 1 \\
\hline
\end{tabular}


Table 3. Eigenvalues, percent of variance, cumulative eigenvalue, cumulative percent of variance for the factor analysis of hydrochemical data.

\begin{tabular}{ccccccccccc}
\hline & F1 & F2 & F3 & F4 & F5 & F6 & F7 & F8 & F9 & F10 \\
\hline Total & 6.87 & 1.68 & 0.82 & 0.29 & 0.20 & 0.09 & 0.03 & 0.02 & 0.00 & 0.00 \\
$\begin{array}{c}\text { Percent of } \\
\text { variance (\%) }\end{array}$ & 68.69 & 16.80 & 8.20 & 2.93 & 1.99 & 0.88 & 0.34 & 0.16 & 0.00 & 0.00 \\
$\begin{array}{c}\text { Cumulative } \\
\text { percent (\%) }\end{array}$ & 68.69 & 85.49 & 93.69 & 96.62 & 98.61 & 99.49 & 99.84 & 100.00 & 100.00 & 100.00 \\
\hline
\end{tabular}

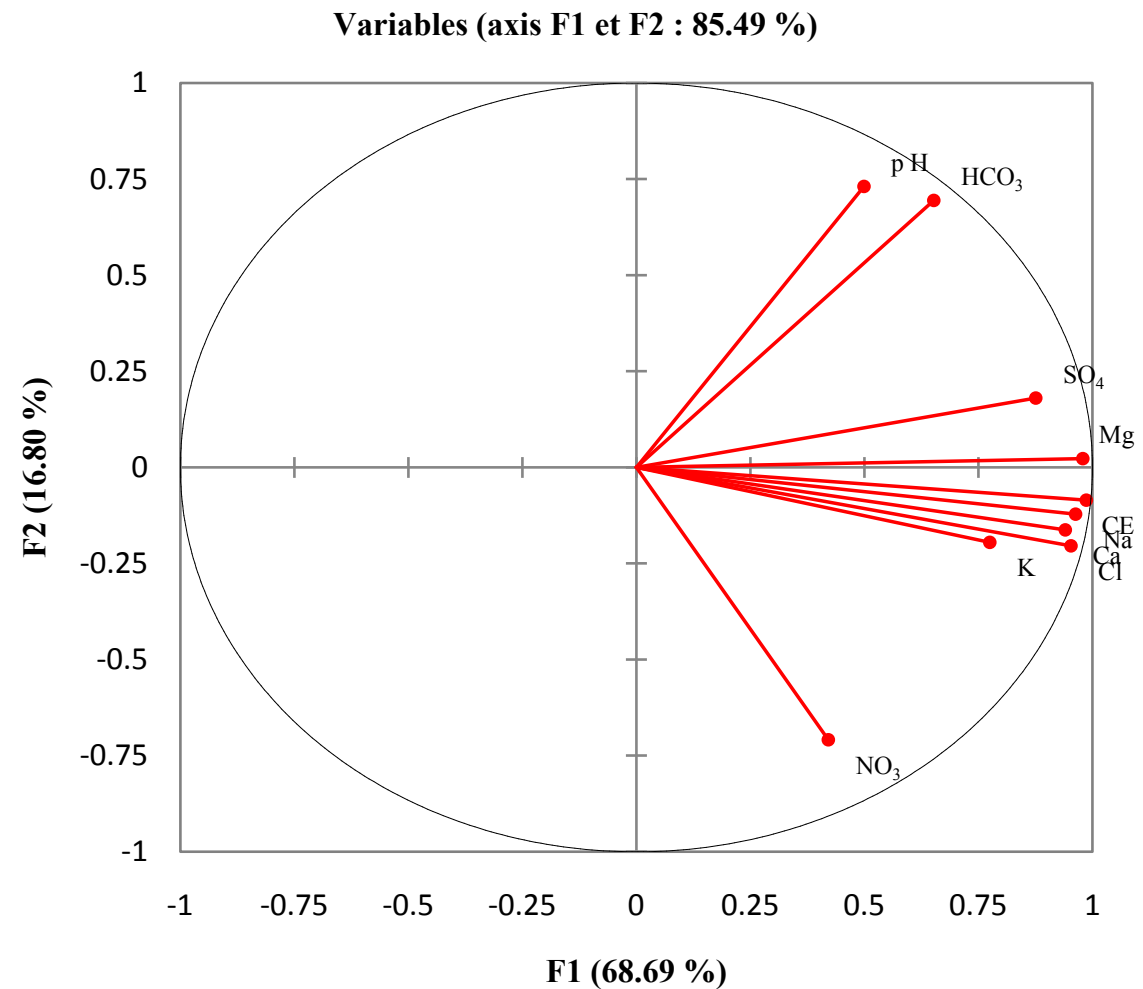

Figure 8. Distribution of physicochemical variables in the correlation circle according to the factorial plane F1 - F2.

shows a strong correlation of electrical conductivity with major elements except $\mathrm{HCO}_{3}^{-}$and $\mathrm{NO}_{3}^{-}$. This correlation varies between 0.716 and 0.988 . These strong correlation values express the contribution of major elements in electrical conductivity. The correlations of $\mathrm{Cl}^{-}$with $\mathrm{SO}_{4}^{2-}, \mathrm{Ca}^{2+}, \mathrm{Mg}^{2+}, \mathrm{Na}^{+}$and $\mathrm{K}^{+}$are strong.

The correlation coefficient varies between 0.714 and 0.988 . These correlations corroborate the common origin of these major elements which could be marine and/or by a dissolution of carbonate, evaporitic minerals.

From the eigenvalues (Table 3), two principal components (F1 and F2) are retained. These components represent $85.49 \%$ of the total variance. The choice of the components ( 1 and 2) is based on the criterion of Kaiser (1960), according to which, factors with eigenvalues greater than or equal to 1 are considered as 
possible sources of variance. The factor 1 (F1) expresses $68.69 \%$ of the total variance, and is represented positively by $\mathrm{EC}, \mathrm{Na}^{+}, \mathrm{K}^{+}, \mathrm{Mg}^{2+}, \mathrm{Ca}^{2+}, \mathrm{Cl}$ and $\mathrm{SO}_{4}^{2-}$. This factor appears as a factor of mineralization. It would reflect the dissolution of carbonate, evaporite formations and/or a saline intrusion. On the other hand, the second factorial axis (F2) represents $16.80 \%$ of the total variance. This factor is characterized positively by $\mathrm{HCO}_{3}^{-}$and $\mathrm{pH}$, and negatively by $\mathrm{NO}_{3}^{-}$. The opposition of these two anions in the space of variables, reflects two different origins of these elements. This difference could be explained by an anthropogenic origin (domestic and agricultural activities) of nitrates $\left(\mathrm{NO}_{3}^{-}\right)$, and bicarbonates $\left(\mathrm{HCO}_{3}^{-}\right)$would come from the dissolution of carbonates.

\section{Conclusion}

The $\mathrm{pH}$ varies between 5.35 and 8.00 with an average of 6.61 indicating acidic water overall. The electrical conductivity values vary between 37.4 and 12,320 $\mu \mathrm{S} \cdot \mathrm{cm}^{-1}$ with an average of $729.3 \mu \mathrm{S} \cdot \mathrm{cm}^{-1}$. The higher conductivities are recorded around the ocean and the Saloum River. These strong conductivities indicate more mineralized waters in this part of the zone. On the other hand, lower conductivities are recorded in the center, south, east and south-east of the southern zone of Saloum. Geochemistry and multivariate statistical analysis show three groups of the sampled structures. These groups are mainly composed of the calcium bicarbonate facies, the sodium bicarbonate facies, the calcium chloride facies and the sodium chloride facies. Group 1 largely occupies the study area with the presence of these four main facies. Calcium and sodium bicarbonate waters, less mineralized, are mostly located in the center and east of the southern zone of Saloum. On the other hand, the calcium chloride facies and the sodium chloride facies are for the most part located in the northern and western parts. This group 1 presents good quality water, with the exception of a few sites which have nitrate levels higher than the WHO standard. Group 2 is present in the center, east, west and north of the southern zone of Saloum. This group consists mainly of the calcium bicarbonate facies and the sodium bicarbonate facies, and its mineralization is moderate. Group 3 is formed from the sodium chloride facies and is located to the north and west of the zone, the southern zone of Saloum (near the river and the ocean). The conductivity and chloride concentration of groundwater increases the closer you get to the Saloum River and the ocean. These increases suggest saline intrusion into the system. This intrusion would come from the salty waters of the river and the ocean. Strong correlations are obtained from the results of the binary diagrams and the PCA. These strong correlations confirm the saline intrusion into the aquifer system south of Saloum. The calculated base exchange indices suggest a base exchange phenomenon between the waters and the formations of the terminal continental water table. The saturation indices suggest an undersaturation of the water in relation to carbonate and evaporitic minerals. Consequently, these minerals would contribute to the mineralization of the groundwater of the aquifer of the terminal con- 
tinental south of Saloum.

\section{Acknowledgements}

The authors thank the sanitary engineering laboratory of Polytechnic School of Thies and the laboratory of hydrochemistry of Cheikh Anta Diop University of Dakar (UCAD) for the chemical analyses carried out. They also thank the Directorate General of Water Resources Planning (DGPRE) for making chemical data available.

\section{Conflicts of Interest}

The authors declare no conflicts of interest regarding the publication of this paper.

\section{References}

[1] Dieng Ndao, N. (2017) Etude de la relation eaux de surface-eaux souterraines dans un contexte de changements climatiques dans la zone Sud du bassin du Saloum (Sénégal) Apport des outils géochimiques, isotopiques, de la télédétetion des SIG et de la modélisation. Université de Liège, Liège.

[2] Sagna, P., Ndiaye, O., Diop, C., Diongue Niang, A. and Sambou, P.C. (2015) Les variations récentes du climat constatées au Sénégal sont-elles en phase avec les descriptions données par les scénarios du GIEC? Pollution Atmosphérique, 227, 1-17.

[3] Faye, S. (2005) Apports des outils géochimiques et isotopiques à l'identification des sources de salinité et à l'évaluation du régime d'écoulement de la nappe du Saloum. Université Cheikh Anta Diop, Dakar.

[4] Faye, M., Guissé, A. and Diallo, N. (2007) Influence du pH, de la salinité de l'eau et de la texture du sol sur la végétation de la mangrove de l'estuaire du Saloum au Sénégal. Journal des Sciences et Technologie, 5, 8-17.

[5] Ndoye, S., Ba, M.I. and Faye, S. (2014) Hydrodynamique de la nappe côtière du Saloum (Sénégal): Étude par modèle numérique. Sciences Appliquées et de l'Ingénieur, 1, 72-78.

[6] Fadili, A. (2014) Etude hydrogéologique et géophysique de l'extension de l'intrusion marine dans le Sahel de l'Oualidia (Maroc): Analyse statistique, hydrochimie et prospection électrique. Univérsité de Chouaïb Doukkali Faculté Des Sciences, El Jadida.

[7] Ndoye, S. (2003) Comportement hydrodynamique et hydrochimique de la nappe côtière du Continental Terminal du Saloum. Université Cheikh Anta Diop, Dakar.

[8] Dieng Ndao, N., Orban, P., Otten, J., Stumpp, C., Faye, S. and Dassargues, A. (2017) Temporal changes in groundwater quality of the Saloum coastal aquifer. Journal of Hydrology: Regional Studies, 9, 163-182. https://doi.org/10.1016/j.ejrh.2016.12.082

[9] Diluca, C. (1976) Etude hydrogéologique du Continental Terminal entre le Sine et la Gambie deuxième phase et rapport de synthèse. BRGM, Dakar.

[10] Faye, S. (2004) Apport des outils chimiques à l'identification des sources de salinité et des processus géochimiques dans la nappe du Saloum (Sénégal). Chez Colloque International "TERRE et EAU", Centre de Recherche Scientifique et Technique sur les Régions Arides, Annaba.

[11] Faye, S., Cissé Faye, S., Ndoye, S. and Faye, A. (2003) Hydrogeochemistry of the Saloum (Sénégal) Superficial Coastral Aquifer. Environmental Geology, 44, 127-136. https://doi.org/10.1007/s00254-002-0749-y 
[12] Faye, S., Maloszewski, P., Stichler, W. and Trimborn, P. (2005) Groundwater Salinization in the Saloum (Senegal) Delta Aquifer: Minor Elements and Isotopic Indicators. Science of the Total Environment, 343, 243-259. https://doi.org/10.1016/j.scitotenv.2004.10.001

[13] Faye, S., Diaw, M., Ndoye, S., Malou, R. and Faye, A. (2009) Impacts of Climate Change on Groundwater Recharge and Salinization of Groundwater Resources in Senegal. Groundwater and Climate in Africa, 334, 163-173.

[14] Faye, S., Ba, M.I., Diaw, M. and Ndoye, S. (2010) The Groundwater Geochemistry of the Saloum Delta Aquifer: Importance of Silicate Weathering, Recharge and Mixing Processes. African Journal of Environmental Science and Technology, 4, 815-830.

[15] Faye, S., Thierion, C., Dacosta, H., Ka, O. and Diagne, D. (2017) Etude hydrogéologiques et hydrologiques complémentaires de la nappe du Continental Terminal de la zone Sine-Gambie. DGPRE, Dakar.

[16] Ndoye, S. (2001) Contribution à l'étude hydrodynamique et hydrochimique de la nappe phréatique du Continental Terminal de la zone Sine Gambie. Université Cheikh Anta Diop, Dakar.

[17] Noël, Y. (1975) Etude hydrogéologique du Continental Terminal de Sine Gambie.

[18] Sarr, B. (2000) Contribution à l'étude hydrogéologique des aquifères de l'Ouest du bassin du Sénégal. Faculté des Sciences et Techniques, Université Cheikh Anta Diop, Dakar.

[19] Lienou, G. (1996) Relations écoulements de surface-écoulements souterrains dans le bassin versant de la Néma (Sine-Saloum, Sénégal). Université Cheikh Anta Diop, Dakar.

[20] Houmed-Gaba, A. (2009) Hydrogéologie des milieux volcaniques sous climat aride. Caractérisation sur site expérimental et modélisation numérique de l'aquifère basaltique de Djibouti (Corne de l'Afrique). Université de Poitiers, Poitier.

[21] Yao, K.A., Kouassi, A.M., Koffi, Y.B. and Biemi, J. (2010) Caractérisation hydrodynamique et hydrogéochimique des aquifères fissurés de la région de Toumodi (centre de la Côte d'Ivoire). Journal of Environmental Hydrology, 18, 1-15.

[22] Ahmed, A.H. (2014) Caractérisation hydrogéochimique et qualité des eaux souterraines du système aquifère volcano-sédimentaire cotier sous climat aride de Djibouti (Afrique de l'est). Université Lille 1, Lille.

[23] Rashrash, S., Ghawar, B. and Hweesh, A. (2015) Evaluating Groundwater Pollution Using Hydrochemical Data: Case Study (Al Wahat Area East of Libya). Journal of Water Resource and Protection, 7, 369-377.

https://doi.org/10.4236/jwarp.2015.74029

[24] Hamzaoui Azaza, F., Bouhlila, R. and Gueddari, M. (2012) Caractérisation de la minéralisation des eaux de la nappe des grès du Trias (Sud-Est Tunisie) par les méthodes géochimiques et statistiques. Géologie, Géographie et Ecologie tropicales, 36, 49-62.

[25] Douagui, A.G., Kouame, I.K., Koffi, K., Dibi, B., Konan, F.K. and Savane, I. (2009) Origines et modélisation de la minéralisation des eaux du Quaternaire d'Abidjan (Sud de la Côte d'Ivoire). International Journal of Biological and Chemical Sciences, 3, 856-869. https://doi.org/10.4314/ijbcs.v3i5.51049

[26] Amrani, S. and Hinaje, S. (2014) Hydrodynamisme et minéralisation des eaux souterraines de la nappe phréatique plio-quaternaire du plateau Timahdite-Almis Guigou (moyen Atlas, Maroc). European Scientific Journal, 10, 174-189.

[27] Appelo, C. and Postama, D. (2005) Geochemistry, Groundwater and Pollution. 2nd 
edition, CRC Press, London, 634. https://doi.org/10.1201/9781439833544

[28] Tellam, J. and Lloyd, J. (1986) Problems in the Recognition of Seawater Intrusion by Chemical Means: An Example of Apparent Chemical Equivalence. Quarterly Journal of Engineering Geology and Hydrogeology, 19, 389-398. https://doi.org/10.1144/GSL.QJEG.1986.019.04.05

[29] Fidelibus, M. and Tulipano, L. (1996) Regional Flow of Intruding Sea Water in the Carbonate Aquifers of Apulia (Southern Italy). Chez 14th Salt Water Intrusion Meeting, Malmo, 17-21 June 1996, 230-240.

[30] Tellam, J.H. (1995) Hydrochemistry of the Saline Groundwaters of the Lower Mersey Basin Permo-Triassic Sandstone Aquifer, UK. Journal of Hydrology, 165, 45-84. https://doi.org/10.1016/0022-1694(94)02583-W

[31] El Achheb, A., Mania, J. and Mudry, J. (2003) Mécanismes d'acquisitions de la minéralisation des eaux souterraines dans le bassin Sahel-Doukkala (Maroc Occidental) approche par des traceurs hydro-géochimiques. Instituto Geológico y $\mathrm{Mi}$ nero de España, Madrid, 113-123.

[32] Yidana, S.M., Ophori, D. and Banoeng-Yakubo, B. (2008) A Multivariate Statistical Analysis of Surface Water Chemistry Data-The Ankobra Basin, Ghana. Journal of Environmental Management, 86, 80-87. https://doi.org/10.1016/j.jenvman.2006.11.023

[33] Meng, S. and Maynard, J. (2001) Use of Statistical Analysis to Formulate Conceptual Models of Geochemical Behavior: Water Chemical Data from the Botucatu Aquifer in Sao Paulo state, Brazil. Journal of Hydrology, 250, 78-97.

https://doi.org/10.1016/S0022-1694(01)00423-1

[34] Biémi, J. (1992) Contribution à l'étude géologique, hydrogéologique et par télédétection des bassins versants Subsahéliens du socle précambrien d'Afrique de l'Ouest: Hydrostructurale, hydrochimie et isotopie des aquifères discontinus des sillons et aires granitiques de la haute Marahoué (Côte d'Ivoire). Thèse de Doctorat, D'Etat, University Nationale de Côte d'Ivoire, Abidjan.

[35] Templ, M., Filzmoser, P. and Reiman, C. (2008) Cluster Analysis Applied to Regional Geochimical Data: Probems and Possibilities. Applied Geochemistry, 23, 2198-2213. https://doi.org/10.1016/j.apgeochem.2008.03.004

[36] Ouhamdouch, S., Bahir, M., Chkir, N., Carreira, P. and Goumih, A. (2016) Comportement hydrogéochimique d'un aquifère cotier des zones semi-arides: Cas de l'aquifère Bar-remien-Aptien du bassin d'Essaouira (Maroc Occidental). Larhyss Journal, 25, 163-182.

[37] St-Hilaire, A., Brun, G., Courtenay, S.C., Ouarda, T.B., Boghen, A.D. and Bobée, B. (2004) Multivarariate Analysis of Water Quality in the Richibucto Drainage Basin (New Brunswick, Canada). Journal of the American Water Resources Association, 40, 691-703. https://doi.org/10.1111/j.1752-1688.2004.tb04453.x

[38] Alaya, M.B., Zenmi, M., Mamou, A. and Zargouni, F. (2014) Acquisition de salinité et qualité des eaux d'une nappe profonde en Tunisie: Approche statistique et géochimique. Hydological Sciences Journal, 59, 395-419.

https://doi.org/10.1080/02626667.2013.870663

[39] Cloutier, V., Lefebvre, R., Therrien, R. and Savard, M.M. (2008) Multivariate Statistical Analysis of Geochemical Data as Indicative of the Hydrogeochemical Evolution of Groundwater in a Sedi-Mentary Rock Aquifer System. Journal of Hydrology, 353, 294-313. https://doi.org/10.1016/j.jhydrol.2008.02.015

[40] N'guettia, G.K., Oimangoua, J.M., Aboua, N.K., Douagui, A.G. and Gone, L.D. (2019) Caractérisation hydrogéochimique des eaux souterraines du bassin versant 
de la Baya, Est Côte d'Ivoire. International Journal of Biological and Chemical Sciences, 13, 547-585. https://doi.org/10.4314/ijbcs.v13i1.44

[41] Farnham, I., Johannesson, K.H., Singh, A.K., Hodge, V.F. and Stetzenbach, K.J. (2003) Factor Analytical Approaches for Evaluating Grounwater Trace Element Chemistry Data. Analytica Chimica Acta, 490, 123-138. https://doi.org/10.1016/S0003-2670(03)00350-7

[42] Nahar, M. and Zhang, J. (2012) Assessment of Potable Water Quality Including Organic, Inorganic, and Trace Metal Concentrations. Environmental Geochemistry and Health, 34, 141-150. https://doi.org/10.1007/s10653-011-9397-z 